\title{
Contestable motives of reporting sexual assault based on research conducted in the region of Silesia
}

\begin{abstract}
Contestable motives of filing reports comprise a set of factors which were not present in the origin of the reported criminal act, as stated by the reporting individual. The objective of such reports is to create circumstances which would lead to the either an imaginary or implicated perpetrator being brought to criminal justice. These types of reports generate a number of doubts and investigative problems. Recently, in the light of newly introduced legislative changes into the methods of investigative procedures in relation to sexual assault (at present these are investigated as an indictable offence - prosecuted ex-officio), this issue has become much more significant. The following publication includes a detailed description of the legal and psychological situation of an individual who has been classified as a victim in a case of sexual assault. The article includes an analysis of statistical data encompassing the period after the introduction of the aforementioned legislative changes in the type of investigative procedures as well as a qualitative analysis of the major factors influencing the process of filing contestable reports of such crimes. The research has been conducted on the basis of analysing a total of 50 cases. It is the opinion of the author that an expert court psychologist, whose presence is mandatory in these types of cases and whose opinion formulated in the course of preparatory proceedings ought to play a key role in the disclosure of false pretences accompanying such reports.

Key words: Contestable motives of filing reports, offence prosecuted ex-officio / indictable offence, offence prosecuted on complaint, lack of sufficient data bearing the marks of a criminal act
\end{abstract}

\section{Introduction}

The objective of this article is the analysis of the psychological patterns on the basis of which contestable motives for reporting sexual offences or attempted rape occur, in the light of legislation in accordance with art. 197 of the Penal Code. The research is based on a representative analytical sample.

Contestable motives for filing reports were first mentioned and described as a subject of literature by Steller and Boychuck in 1989. Global literature to this day lacks descriptions of this type of factor, which commonly appears in the context of criminal investigations. The aforementioned authors formulated these factors in a control list based on the truthfulness of testimony given by witnesses and victims (Validity Checklist). The motives which served as criteria presented by the authors, apart from contestable motives of filing a report, also included: the contestable or dubious context of the incident's disclosure/filing the report under pressure induced to give full and truthful testimony (Steller, 1989; Steller, Boychuck, 1992).

I shall treat the contestable motives of filing a report as a set of factors (headed by the prime motive), which did not appear in the origin of the reported crime) which have been described by the individual filing the report. Their objective is a conscious or subconscious creation of circumstances which would lead to the nonexistent or implicated perpetrator to be brought to criminal justice. In other words, the victim has an unclear reason to file a false report.

This may, for example, concern relations between the victim and the suspect, or possible consequences for the viewing prosecution of all parties involved in the incident. (Seller, Boychunk, 1992).

Sexual assault belongs to the type of criminal act which produces a strong social reaction. Moreover, when faced with such acts committed in a serial manner, the local community is fraught with a decreased sense of security, fear and social unease. (Lach, 2014). According to sociological research, unsolved sexual crimes also have a negative impact on society's perception of the police (Craft, 1996). Rape belongs to a group of incidents which not only causes harm to the victim physically, but also psychologically. On the other hand, some cases of reported sexual assault generate investigatory problems related with contestable or, at the least, doubtful motives behind the 
filing of such reports - namely situations in which a crime has been reported but not, in fact, committed. (Litmann and Szewczyk, 1983).

In this category of reports, it is, much in advance in fact, well known that the operational activities carried out by the police are destined to fail, as the perpetrator either indicated or described by the victim does not exist at all, or the reported incident took place in circumstances much different to those described by the victim. Such situations actually happen more often that it is commonly thought.

So far, practice has shown that the investigatory process of this type of felony engages large amounts of resources, both connected with police activity as well as financial resources (Lach, 1999). If it is the case that, in the initial phase of the investigation, the contestable motives functioning within the sphere of the reported incident have not been exposed, then in the course of the investigation, these difficulties tend to mount, generating the need for additional financial means being dedicated to the topic. This also engages the activities of a substantial number of police officers. If this be the case, financial resources spent on investigating these reports are irrational and the engagement of police officers in a case which is bound to end in an investigative failure, thus resulting in the irrational use of human resources.

Actual sexual assault instigates a number of complications for the victim, both mental as well as behavioural. These include, amongst others:

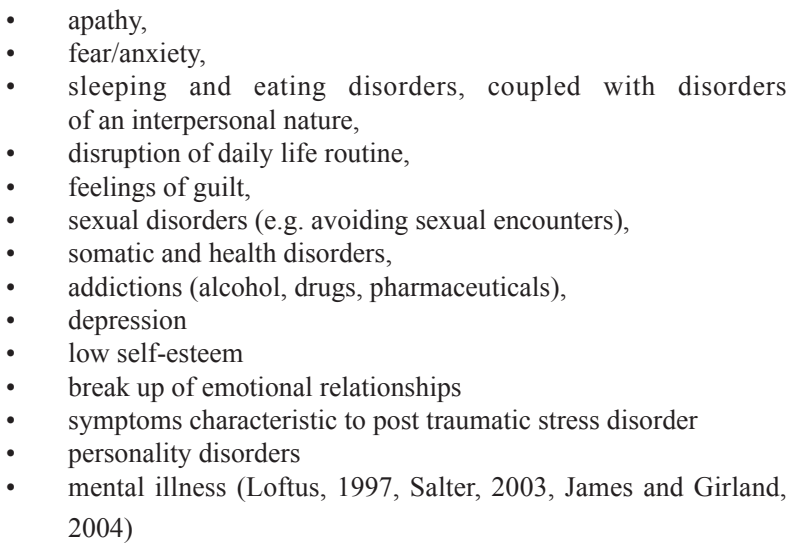

The victims of sexual assault are far more often subject to psychological and social consequences, which can have a diverse character and demonstrate a tendency to become more permanent in their duration. Their physical and emotional repercussions are usually observed in unison, as part of a complex process. This process is characterised by a tendency for self-consolidation.

From a legal standpoint, bringing the culprit responsible for the crime to justice demands, first of all, for the law enforcer to obtain information which would confirm that a felony has actually been committed. Secondly, there is a need to determine the identity of the individual accountable for the crime. Successful investigation into the criminal act may be guaranteed either through obtaining adequate information from one of the involved parties (an eyewitness of the event, the guardian, the victim), from an institution (health care unit, therapist's office, school, auxiliary institution) or through the activities of the law enforcers themselves (Marcinkiewicz, 2010). In cases where the investigation revolves around a felon who is well known to the victim, this does not generate significant difficulties. On the other hand, in cases where the identity of the perpetrator remains unknown to the victim, the number of investigative problems decisively increases. From an operational point of view, police officers undertaking investigatory processes tend to fall back on stereotypes, especially in those cases in which the parties involved are well-known to them, either through a negative opinion circulating in their social environment or from the lifestyle they lead. This phenomenon is a significant factor which influences the proceeding of the investigation as, at times, it will create distortions in the perception of events which have taken place.

From the police's point of view, investigations leading to proving that a crime has not been committed fall much lower on the priority list composed by appropriate decision-makers, as opposed to those cases in which a felony actually occurred. This is due to the fact that the effect of such investigations does not have any positive influence on police statistics and neither are they judged as cases which would bear any positive influence on the image of the police as an institution.

Based on topical literature and an analysis of investigatory material, the following questions have been formulated: (1) What type of demographic details characterise alleged perpetrators of sexual assault, as well as individuals filing reports connected with these incidents? (2) What is the pattern of the motives which may be perceived as contestable? (3) Is it possible to differentiate factors influencing the process of giving testimony by individuals who have already been classified in their status as victims filing reports of sexual assault?

\section{Method}

Extensive research into available documentation in the form of prosecution and court files was carried out in order to obtain the answers to the afore-mentioned analytical questions. Due to the fact that the problem in question: contestable motives of reporting sexual assault based on research conducted in the region of Silesia, appears to occur relatively rarely in practice, the technique of analysing a representative sample was introduced, based on an analysis of closed cases in which, due to the disclosure of dubious motives for reporting the crime itself, the investigation was closed. A questionnaire was used as the research tool. The results of this survey have been processed on the basis of 50 documented proceedings linked with cases which took place in the area of the Silesian Voivodeship, initiated on the basis of art. 197 of the Penal Code.

\section{The legal pattern of sexual assault}

Since 1997, the act of sexual assault/rape has been categorised by the Penal Code in art. 197, which has 
classified it as a criminal act belonging to the group of felonies investigated on the instantiation of the victim - in other words offences prosecuted on complaint. Since the 20th of January 2014, Polish law has been modified in order to alter the mode of investigation. Since then, this criminal act has been under the jurisdiction of the state (prosecuted in-officio). This amendment in the law has had an impact on the perception of this type of incident by the victims. On the one hand, victims who lead a sexually high-risk lifestyle have a far more common tendency to attempt reporting an incident based on rather dubious grounds in relation to the implicated and alleged perpetrator. On the other hand, individuals in emotionally dysfunctional relationships and ones who experience acts of sexual aggression or assault usually do not attempt to report cases of sexual assault due to experiencing ambiguous emotions of a character based on the approach-avoidance conflict. These emotions are based on what they see as possible legal or penal sanctions for the perpetrator, who may be someone close to them. Additional reasons for such action are often intertwined with further consequences, amongst others ones of a financial and moral nature.

In accordance with the introduction of an amendment in article 185c, since January 2014, legal procedures linked with the methods of questioning victims of sexual assault have now been clearly defined. Since the above-mentioned date, the victim of this felony is to be questioned in front of a judge and in the presence of an expert court psychologist, if possible of the same gender and in premises specially prepared for this purpose.

According to this new law, these activities should be undertaken in the presence of an expert psychologist, who then prepares a follow-up opinion on the victim's testimony. The psychologist should play an active role in questioning the victim.

The changes introduced in the manner of investigating sexual assault generate a number of significant difficulties. In order to illustrate these, I have presented statistical data which encompasses the period after the introduction of the change in the law.

Analysing the period between January and August 2010-2014, there is an observable increase in the number of sexual assaults reported by victims. This tendency clearly rose immediately after the introduction of the change in legislation concerning the mode of investigation. The dynamics of this process are presented in the table below.

A further analysis of statistical data allows us to form a hypothesis that the number of reported sexual assaults of a dubious nature of the motive for which they had, at first, been reported, has increased significantly in relation to those felonies which had actually been committed.

Statistical data collected in the course of the last decade points to the fact that, annually, approximately $15 \%$ of reported sexual assaults remain unsolved. This number includes quite a significant percentage (according to the author - approximately 5\%) of reports based on dubious or contestable motives of the report being filed.

Table 1. Sexual assault in the period between January and August in the years 2010-2014 in the Silesian Region / Voivodeship

\begin{tabular}{cccc}
\hline Year & $\begin{array}{c}\text { Number of initiated } \\
\text { investigations }\end{array}$ & $\begin{array}{c}\text { Number of pronounced } \\
\text { crimes }\end{array}$ & $\begin{array}{c}\text { Investigation success } \\
\text { rate in } \%\end{array}$ \\
\hline 2010 & 146 & 102 & 78,4 \\
2011 & 161 & 93 & 76,3 \\
2012 & 127 & 94 & 88,3 \\
2013 & 153 & 96 & 87,8 \\
2014 & 223 & 114 & 86,2 \\
\hline
\end{tabular}

Source: Police Headquarters statistical bulletin

Table 2. Sexual assault in the period between 2010-2014 in the Silesian Region (January - December)

\begin{tabular}{ccccc}
\hline Year & $\begin{array}{c}\text { Number of initiated } \\
\text { investigations }\end{array}$ & $\begin{array}{c}\text { Number of } \\
\text { pronounced crimes }\end{array}$ & $\begin{array}{c}\text { Investigation success } \\
\text { rate in \% }\end{array}$ & $\begin{array}{c}\text { Assaults committed } \\
\text { by minors }\end{array}$ \\
\hline 2010 & 219 & 179 & 79,0 & 7 \\
2011 & 245 & 157 & 71,3 & 9 \\
2012 & 203 & 157 & 82,5 & 16 \\
2013 & 241 & 178 & 86,7 & 11 \\
\hline
\end{tabular}

Source: Police Headquarters statistical bulletin 
Table 3. Sexual assault in the Silesian Voivodeship between 2010 - 2014.

\begin{tabular}{ccccc}
\hline Year & $\begin{array}{c}\text { Number of initiated } \\
\text { investigations }\end{array}$ & $\begin{array}{c}\text { Number of } \\
\text { pronounced crimes }\end{array}$ & $\begin{array}{c}\text { Investigation success } \\
\text { rate in } \%\end{array}$ & $\begin{array}{c}\text { Assaults committed } \\
\text { by minors }\end{array}$ \\
\hline 2004 & 309 & 298 & 79,3 & 15 \\
2005 & 315 & 305 & 78,4 & 8 \\
2006 & 313 & 302 & 81,3 & 18 \\
2007 & 290 & 284 & 83,9 & 19 \\
2008 & 245 & 238 & 78,8 & 9 \\
2009 & 210 & 171 & 82,5 & 7 \\
2010 & 219 & 179 & 79,0 & 7 \\
2011 & 245 & 157 & 71,3 & 9 \\
2012 & 203 & 157 & 82,5 & 16 \\
2013 & 241 & 178 & 86,7 & 20 \\
\hline
\end{tabular}

Source: Police Headquarters statistical bulletin

\section{Participants}

According to documentation, in $82 \%$ of the filed reports in which the motive for reporting a crime could be deemed as contestable, the reports had been filed by the victims themselves (41 cases) and individuals functioning within their environment ( 9 cases).

An indictment was presented to court in a mere 3 of the analysed cases. These cases were duly closed, with the acquittal of the implicated perpetrator.

\section{Results}

In a total of 47 of these cases $(\mathrm{N}=50)$, the basis for remitting investigatory procedures was a refusal from the prosecution to prosecute (94\%). An analysis of the files connected with the investigation pointed to the fact that in over half $(70 \%)$ of the cases involved (35 cases) the victim had been under the influence of alcohol when the incident took place. The state of inebriation of the individual reporting the event did not allow for a full recreation of the allegedly incriminating sequence of events and was partial to the distortion of facts. The basis of refusal to open an investigation on the part of the prosecution was based on art. 17 par. 1.1 of the Penal Code - relating to the lack of sufficient data justifying the suspected occurrence of a criminal act ( 31 cases equalling $62 \%$ ). In the course of the investigations, a total of 17 victims (34\%) who had previously demanded a police investigation into an alleged crime, subsequently made a statement in which they pronounce that they wish to withdraw their report (the period between January 2010 and January 2014). In 14 of the cases (28\%), the victim refused testimony in the further phases of the investigation and subsequently filed a statement for the closure of the criminal investigation. 16 of the cases $(32 \%)$ were closed due to the fact that the act committed did not bear any marks of a crime, Art. 17 par. 1.1 of the Penal Code.
Perpetrators (or alleged perpetrators) of sexual assault commit most of the criminal acts in open areas. These are usually males between the ages of 31 and 40 (single or divorced), with a primary or secondary level of education and in full-time employment. These relations are predicted on the graphs below.

\section{Graph 1. Site of reported sexual assault}

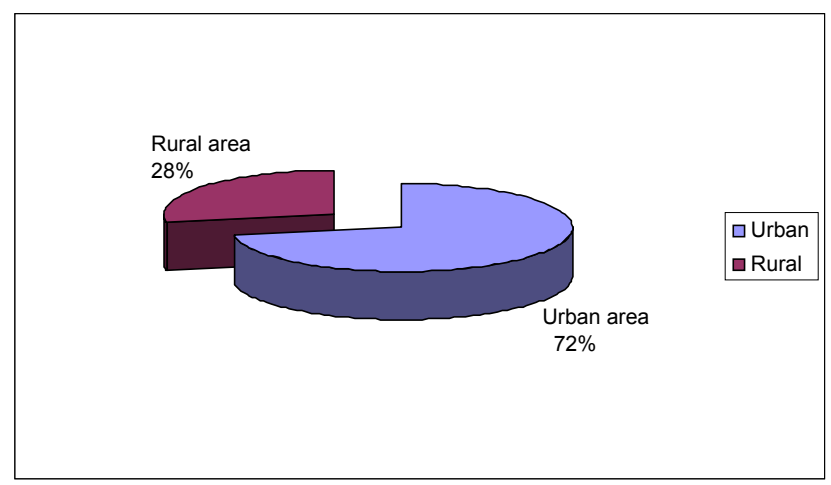

Graph 2. Age description of alleged perpetrator

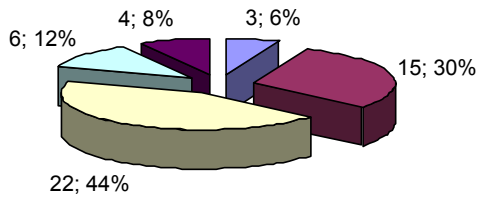

口 18-20 у.о.

$\square$ 21-30 y.o.

口 31-40 y.o.

$\square$ 41-50 y.o.

- 50 and over 
Graph 3

Marital status of the alleged perpetrator of the sexual assault

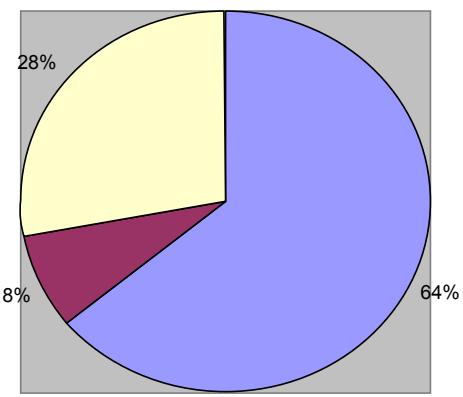

$\square$ divorced

\section{Graph 4. Educational background of alleged perpetrator}

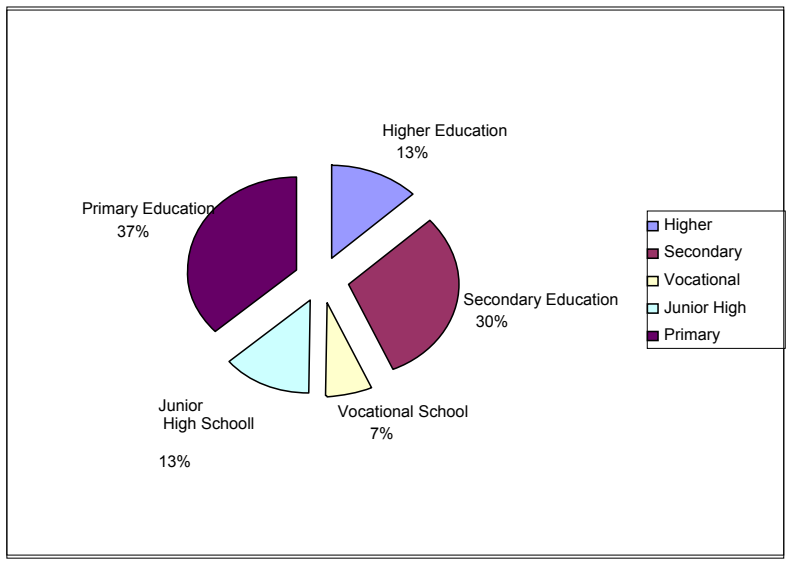

Graph 5. Information concerning employment status of alleged perpetrator

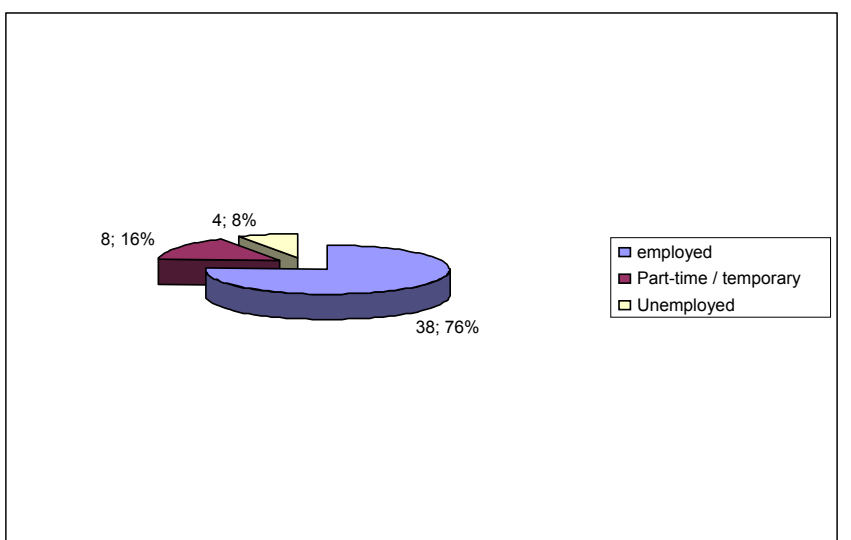

The individuals reporting the incident of sexual assault based on contestable motives are usually single or divorced females in a similar age group as the alleged perpetrators, with a level of education either on a secondary or vocational school level. They are either in full-time employment or unemployed. The characteristic features of this group are presented on the graphs below.
Graph 6. A description of the age of individuals filing contestable reports of sexual assault

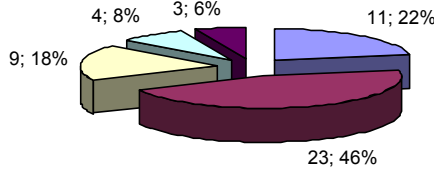

$\square 31-40$ y.o.

$\square 41-50$ y.o.

- 50 y.o. and ove

Graph 7. Marital status of individuals filing contestable reports of sexual assault

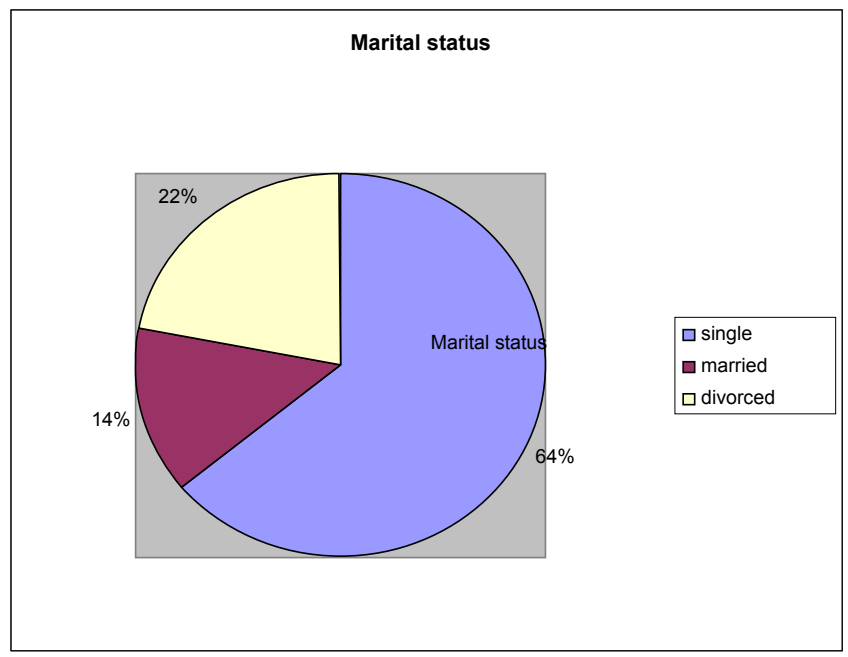

Graph 8. A description of the educational background of individuals filing contestable reports of sexual assault

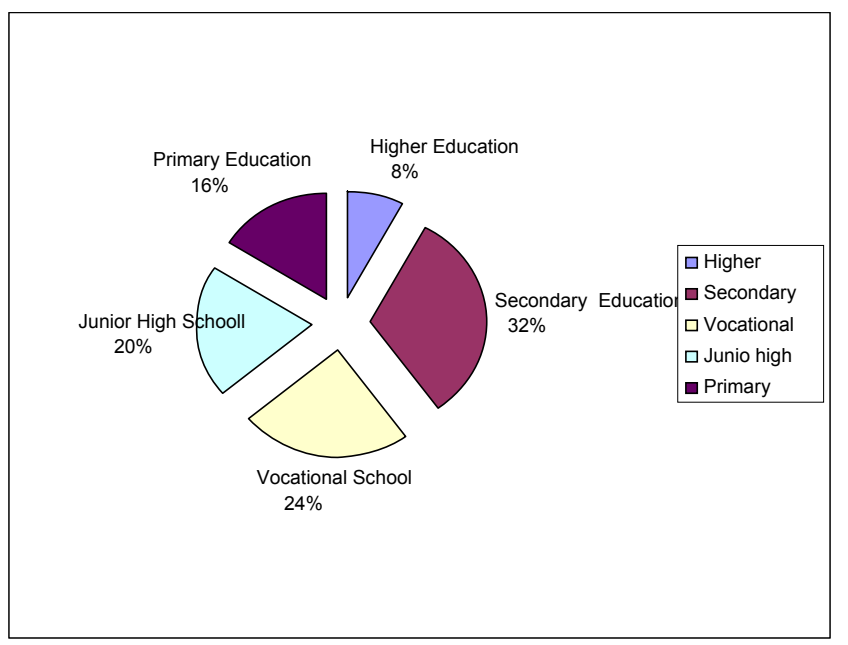


Graph 9. Details concerning employment of individuals filing contestable reports of sexual assault

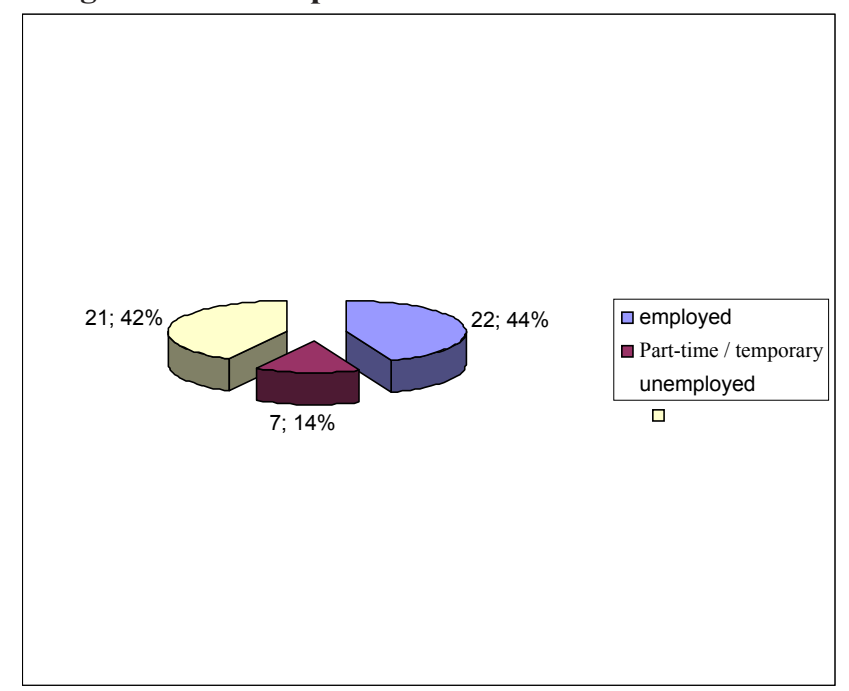

Research conducted in this field has allowed for a differentiation between a variety of factors influencing the process of filing a report by the alleged victims - which may all be construed as dubious. It is worth emphasising here that the description of a sole motive is a gross simplification. Modern psychology has long done away with using the term 'motive' as a factor which regulates and determines the direction of human behaviour. Nowadays it is more common to use the term in relation to processes based on a complex mental phenomenon, which take into consideration a whole variety of internal variables (personality-based) and external (situation-based). Of course, most felonies are characterised by their multiple motives. (Lach, 2014). An analysis of police files has pointed towards the following dubious motives characterising the individual filing the report:

- $\quad$ economic motives (the lack of / failure to pass over material gain through the rendering of services)

- jealousy (connected with meeting a new partner and ending the relationship with the person filing the report)

- $\quad$ anxiety (induced by foreseen consequences, 'I've had intercourse, which could or could have resulted in a pregnancy, how will my present partner, parents react?) (por. Gruza, 2003)

- achieving a 'better bargaining position' - e.g. in a divorce case, or in a case related to child custody (Bow J.N., Quinnell F.A., Zaroff M., Assmany A., 2002)

- fear (filing a report in order to avoid a foreseeable labelling of the person filing the report within the local environment a case of "others will probably think that I was too loose/easy")

- a sense of injury and resentment (promises not kept by the indicated perpetrator in relation to leaving their present partner)

- delusional motives (the indicated perpetrator was supposed to be my partner)

- $\quad$ erotic motives (the indicated perpetrator refused to engage in sexual intercourse)

- $\quad$ negative attribution (the intentions behind the meeting with the indicated perpetrator was not in line with the preconceptions of the person filing the report),

- revenge (unlawful allegations made in the case of an innocent individualas aresultofbroken emotional, materialorethical promises)
A qualitative analysis of the research material showed that the main factors bearing influence on the process of giving testimony by individuals reporting an incident of sexual assault - who have been classified as victims - include the following:

- $\quad$ personality traits,

- $\quad$ intellectual development,

- abilities of perception (Bow J.N., Quinnell F.A., Zaroff M., Assmany A. 2003),

- mental and physical state of the person filing the report (the influence of alcohol, drugs, stimulants)

- emotional state

- circumstances preceding the incriminating incident,

- the time and place of the incident,

- techniques of implication of the victim by the perpetrator,

- the course of the interaction,

- the victims social situation (Bull R., McAlpine S, 2003),

- the victim's sexual experience,

- $\quad$ quality and quantity of details accompanying the incident,

- factors influencing the formation of possible deviations from the truth,

- bodily harm acquired (or not) in the course of the incident (Bul R, McAlpine S, 2003),

- both the victim's as well as the alleged perpetrator's mental and physical state at the time and during the course of the incident,

- $\quad$ susceptibility to suggestion(s) and the possibility of these occurring,

- the circumstances of the incident's disclosure (the context in the analysed incidents and the time of the reporting was strongly differentiated, amounting to a period between 1 and 96 days after the described incident)

- motives accompanying the disclosure of the incident

\section{Discussion}

Having conducted a psychological analysis of the incidents of sexual assault based on reports of contestable motives on the part of the individuals filing the reports, we can observe a tendency for the described incidents to most commonly take place within an urban area, in premises such as: a flat/apartment, a hotel in evening hours or at night. The individuals reporting the incidents were under the influence of alcohol and the described events usually entailed an individual not unknown to the alleged victim. The external factors presented above were observed in $70 \%$ of the analysed cases.

Judging from the perspective of this analysis, it seems advisable for the law to recognise and implement a change in the legislation which would make it obligatorily for an expert psychologist to take participation in the questioning of the victim of sexual assault. When ascertaining the role of this expert in the process of questioning, this role should be active, based on a mandatory psychological screening of the victim, finalised with a reported opinion including all factors mentioned. The psychological report should be of a holistic character. It is often the case that opinions drawn in these types of cases possess a rather actuarial character (based primarily on an analysis of the testimony and on observations of the person testifying), which is, at the most, insufficient. 


\section{References}

Bow J.N., Quinnell F.A., Zaroff M., Assmany A. (2002), Assessment of Sexual Abuse Allegations in Child Custody Cases. Professional Psychology: Research and Practice 33(6)

Bull R., McAlpine S. (2003), Wyglad twarzy a przestepczość, (w) Menon A, Vrij A, Bull R, Prawo i psychologia. Wydawnictwo GWP. Gdańsk.

Craft D. (1996), Personality assessment. Niepublikowane materiały Federalnego Biura Śledczego Quantico.

Gruza E. (2003), Ocena wiarygodności zeznań świadków w procesie karnym. Wydawnictwo Zakamycze. Kraków.

James R.K., Girland B.E. (2004), Strategie interwencji kryzysowej. Wydawnictwo PARPA. Warszawa.

Marcinkiewicz P. (2010), Psychologiczne aspekty wykrywania przestępstw seksualnych (w) red. Polczyk R., Dukała K., Przestępstwa seksualne z perspektywy psychologicznej i prawnej. Wydawnictwo UJ. Kraków.

Lach B. (1999) Niektóre psychologiczne determinanty tworzenia portretu psychologicznego sprawcy, w: M. Zajder i M. Goc (red.), Nowoczesność oględzin procesowo-kryminalistycznych. Wydawnictwo Wyższej Szkoły Policji w Szczytnie, Szczytno (s. 258-271).

Lach B. (2014), Profilowanie kryminalistyczne. Wydawnictwo Wolters Kluwer. Warszawa. Littmann E., Szewczyk H. (1983). Zueinigen Kriterien und Ergebnissen forebnsisch-psychologischer Glaubbwurdigkeitsbegutachtung von sexuell misbrachuchten Kinderem und Jugendlichen. Forensia, 4, 55-72.

Loftus E. F. (1997), Fabrykowanie wspomnień. W: Świat Nauki, nr.11. Warszawa.

Salter A.C. (2003), Pokonywanie traumy. Jak zrozumieć i leczyć doroste ofiary wykorzystywania seksualnego w dzieciństwie. Media Rodzina. Poznań.

Steller M. (1989), Recent developments In stateesment analysis. W: Yullie J. C. (1989), Crediibility Assesment (s. 135-154). Deventer, The Netherlands: Kluwer.

Steller M. , Boychunk T. (1992), Children as witnesses in sexual abuse cases: Investigative, interview and assessment techniques. W: Dent H, Fin R. (red.), Children as Witnesses (s.47-73). New York: John Wiley and Sons. 